University of Nebraska - Lincoln

DigitalCommons@University of Nebraska - Lincoln

Entomology Papers from Other Sources

Entomology Collections, Miscellaneous

1981

\title{
Eli Lilly EL-468, a New Bait Toxicant for Control of the Red Imported Fire Ant
}

David F. Williams

USDA

Clifford S. Lofgren

USDA

Follow this and additional works at: https://digitalcommons.unl.edu/entomologyother

Part of the Entomology Commons

Williams, David F. and Lofgren, Clifford S., "Eli Lilly EL-468, a New Bait Toxicant for Control of the Red Imported Fire Ant" (1981). Entomology Papers from Other Sources. 27.

https://digitalcommons.unl.edu/entomologyother/27

This Article is brought to you for free and open access by the Entomology Collections, Miscellaneous at DigitalCommons@University of Nebraska - Lincoln. It has been accepted for inclusion in Entomology Papers from Other Sources by an authorized administrator of DigitalCommons@University of Nebraska - Lincoln. 


\title{
ELI LILLY EL-468, A NEW BAIT TOXICANT FOR CONTROL OF THE RED IMPORTED FIRE ANT ${ }^{1,2}$
}

\author{
DAvid F. WILLIAMS AND CLIFFORd S. LOFGREN \\ Insects Affecting Man and Animals Research Laboratory, \\ Agricultural Research Service, \\ USDA, Gainesville, FL 32604 USA
}

\begin{abstract}
Eli Lilly EL-468, a phenylenediamine, possesses the delayed-toxicity necessary for a bait toxicant to control colonies of the red imported fire ant, Solenopsis invicta Buren. In laboratory tests it gave delayed action over more than a 10-fold range of concentrations; in field tests, baits formulated on pregel defatted corn grits and applied at 20 and $40 \mathrm{~g} \mathrm{AI} /$ ha produced as high as 86 and $91 \%$ control.
\end{abstract}

\section{RESUMEN}

Eli Lilly EL-468, una fenilenodiamina, tiene la toxicidad retardada que se nesecita para poder usarlo con cebos para controlar las colonias de la hormiga roja importada, Solenopsis invicta Buren. En pruebas de laboratorio se mostró actividad retardada en un rango de concentraciones de 10 incrementos. En pruebas de campo, se obtiuvieron control de hasta 86 y $91 \%$ con cebos formulados con maíz a medio moler con la manteca extraida y la condición "pre-gelatinosa" que fue aplicada a 20 y 40 g IA/ha.

Large-scale control programs for the red imported fire ant (RIFA), Solenopsis invicta Buren, were conducted with mirex baits from the early 1960's through 1977 (Lofgren et al. 1963, 1964, Banks et al. 1973, Alley 1973). On 30 June 1978 the registrations of mirex were cancelled by the Environmental Protection Agency. Justification for the action was attributed to (1) the discovery of mirex residues in the environment (Ludke et al. 1971, Mehendale et al. 1972, Baetcke et al. 1972); (2) its toxicity to estuarine organisms (Lowe et al. 1970, 1971) ; and (3) its carcinogenic properties (Innes et al. 1969, Mrak 1969).

Laboratory and field studies by Williams et al. (1980) and Banks et al. (1981) led to the conditional registration of AC 217,300 (2(1H) -pyrimidinone, tetrahydro-5,5-dimethyl-, [3[4-(trifluoromethyl) phenyl]-1-[2-[4-(trifluoromethyl) phenyl]ethenyl]-2-propenylidene]hydrazone) by the Environmental Protection Agency for the control of RIFA in August, 1980. Presently, this is the only chemical registered for area-wide control of the RIFA.

In an effort to find delayed-action toxicants for use in RIFA baits, USDA (ARS) scientists have evaluated hundreds of chemicals each year, with more than 6,500 chemicals evaluated since 1957. Very few have showed the delayed toxicity required for a bait toxicant (Banks et al. 1977) and only mirex and AC 217,300 were registered for commercial use.

\footnotetext{
${ }^{1}$ Hymenoptera: Formicidae.

${ }^{2}$ Mention of a pesticide, commercial or proprietary product does not constitute an endorsement or recommendation by the USDA.
} 
Recently a new chemical, EL-468, (N-[2-amino-3-nitro-5-(trifluoromethyl) phenyl]-2,2,3,3-tetrafluoropropanamide) produced by Eli-Lilly and Company has shown promise in our laboratory and field studies. In this paper we report the results of these tests.

\section{Materials AND Methods}

Laboratory evaluation procedures for bait toxicants were described by Williams et al. (1980). Chemicals are first evaluated against worker ants in a primary screening test. Those chemicals showing delayed toxicity (defined as $<15 \%$ kill at 1 day but $>89 \%$ after 14 days) are given secondary screening tests against whole laboratory colonies containing a queen and workers in all developmental stages. The chemicals that cause $>90 \%$ mortality in addition to killing or sterilizing the colony queen are selected for small-scale field tests to prove efficacy against natural populations of RIFA.

A brief description of the primary screening test is as follows. Twenty worker ants from laboratory colonies that had been without food for 14 days were placed in $30 \mathrm{ml}$ disposable plastic medicine cups ca. $24 \mathrm{hrs}$ preceding the test. Candidate chemicals were dissolved directly in once-refined soybean oil (SBO) and offered to the ants on cotton swabs placed in small vial caps. The ants were allowed to feed on the treated SBO for $24 \mathrm{hrs}$, then the swabs and vial caps were removed from the cups and the ants remained without food for an additional $24 \mathrm{hrs}$. New vial caps containing cotton swabs saturated with untreated fresh SBO were placed in the cups and left for the remainder of the test period. Knockdown and mortality counts were made at intervals of $1,2,3,6,8,10$, and 14 days following initial exposure. Each test consisted of 3 replications at 3 concentrations, $1.0,0.1$, and $0.01 \%$.

The secondary screening tests were as follows. The chemicals were dissolved at 1.0, 2.5, and 5.0\% by weight in once-refined SBO and then impregnated on pregel defatted corn grits (Lauhoff Grain Company, Danville, Illinois) at $30 \%$ by weight of total formulation. Five grams of the formulated bait were placed in disposable plastic weighing boats $(100 \mathrm{ml} \mathrm{cap.})$ and then each boat was placed in a laboratory colony starved for 5 days prior to the test. The ants were allowed to feed on the bait for $96 \mathrm{hrs}$, then the bait was removed and replaced with the standard laboratory diet of honey-water (1:1) and Bank's diet (Williams et al. 1980). General observations on the condition of the colony and mortality counts (estimation of dead ants and brood) were recorded weekly. The tests were continued until the queen, brood, and $>90 \%$ of the workers were dead (in the case of the queen, complete sterility was sufficient) or the colony had recovered and returned to a normal condition. This condition was considered reached after the queen resumed egg laying and all stages of immatures were present. Each concentration was tested against 2 laboratory colonies consisting of 60 to 120 thousand workers and 50 to $60 \mathrm{ml}$ of brood.

The field tests were conducted in Hamilton County, Florida. The chemical was dissolved at 2.5 and $5.0 \%$ by weight in once-refined SBO. Pregel defatted corn grits were impregnated with the oil solution at $30 \%$ by weight of total formulation to yield baits containing 0.75 to $1.5 \%$ active ingredient. The baits were applied with a tractor-mounted auger applicator (Williams et al. unpublished data) at 20 and $40 \mathrm{~g} \mathrm{AI} / \mathrm{ha}$ ( 8.4 and $16.5 \mathrm{~g} \mathrm{AI} / \mathrm{A}$ ). Amdro ${ }^{\circledR}$, which is a formulated bait of AC 217,300 from American Cy- 
anamid Company, Princeton, New Jersey, was applied as a standard at $10 \mathrm{~g}$ $\mathrm{AI} / \mathrm{ha}$ (4.3 $\mathrm{g} \mathrm{AI} / \mathrm{A})$ for comparison. All treatments were conducted on 0.4 ha plots ( 3 replications per treatment) located in non-grazed permanent pasture. Controls were 3 untreated plots ( 0.4 ha each).

Pre- and post-treatment counts of the number of active nests, the size of the nests, and the presence (normal) or absence (abnormal) of worker brood were recorded from 0.2 ha $(0.5$ acre $)$ circles within each treatment block.

The percentage control in the field tests was determined by making posttreatment evaluations at 6,12 , and 21 wk intervals using the method described by Harlan et al. (1981). This method uses a 10-point system to rate each colony based on the absence (categories 1-5) or presence (categories 6-10) of worker brood. A normal colony of RIFA should contain worker brood, particularly during the warmer months of the year, thus a colony without worker brood would indicate the absence of a queen or the presence of a sterile queen. Also, each colony was rated on its size (no. of worker ants) ranging from $<100$ workers (categories 1 and 6 ) to $>50,000$ (categories 5 and 10). Therefore, categories 1 and $6(<100), 2$ and $7(100-1000)$, 3 and $8(1000-10000) 4$ and $9(10000-50000)$ and 5 and $10(>50000)$ are all the same size but differ in whether worker brood is present or absent. The number of each category in a plot multiplied by the total number of colonies recorded for that category yields the "population index" for each plot. The difference between the pre- and post-treatment population indexes was used to calculate the percentage control for each treatment.

\section{Results ANd Discussion}

In the laboratory primary screening tests EL-468 exhibited delayed toxicity at the 0.1 and $1.0 \%$ concentrations (Table 1), but it did not show toxicity at the $0.01 \%$ concentration. In comparison, mirex gave delayed kill at all 3 concentrations. When tested in a bait against entire laboratory colonies (Table 2) EL-468 killed 95 to $100 \%$ of the individual ants within each colony in 1 wk and all colonies were dead after 8 wks.

The results of field tests (Table 3) suggest that EL-468 gave better control with both concentrations than the standard, Amdro®, at 6 wks and as good as or slightly better control at 12 wks; however, the differences were

TABLE 1. RESUlts OF PRIMARY SCREENING TESTS With ELI-Lilly EL-468 AGAINST RED IMPORTED FIRE ANTS (AVG. OF 6 TESTS).

\begin{tabular}{|c|c|c|c|c|c|c|c|c|}
\hline \multirow[b]{2}{*}{ Treatment } & \multirow{2}{*}{$\begin{array}{l}\text { Conc. } \\
(\%) \text { in } \\
\text { SBO }\end{array}$} & \multicolumn{7}{|c|}{$\begin{array}{l}\text { Percent knockdown and mortality } \\
\text { after indicated number of days }\end{array}$} \\
\hline & & 1 & 2 & 3 & 6 & 8 & 10 & $\overline{14}$ \\
\hline \multirow[t]{3}{*}{ EL-468 } & 0.01 & 1 & 1 & 1 & 1 & 4 & 8 & 18 \\
\hline & 0.1 & 0 & 4 & 12 & 55 & 79 & 89 & 97 \\
\hline & 1.0 & 4 & 33 & 78 & 100 & & & \\
\hline \multirow[t]{3}{*}{ Mirex standard } & 0.01 & 0 & 1 & 1 & 7 & 39 & 84 & 98 \\
\hline & 0.1 & 1 & 2 & 17 & 66 & 84 & 92 & 100 \\
\hline & 1.0 & 0 & 57 & 90 & 100 & & & \\
\hline Soybean oil check & - & 0 & 0 & 0 & 1 & 2 & 4 & 7 \\
\hline
\end{tabular}


TABLE 2. EFFECT OF CONCENTRATION OF EL-468 AGAINST LAB COLONIES OF RIFA (5 GMS BAIT/COLONY); 30\% SBO ON PREGEL DEFATTED CORN GRITS; 1 COLONY/TREATMENT.

\begin{tabular}{|c|c|c|c|c|c|}
\hline \multirow{2}{*}{$\begin{array}{l}\text { Conc. }(\%) \\
\text { in SBO }\end{array}$} & \multicolumn{5}{|c|}{$\begin{array}{l}\text { Percent knockdown and mortality } \\
\text { after indicated wks* }\end{array}$} \\
\hline & 1 & 2 & 3 & 4 & 8 \\
\hline 1.0 & 95 & 97 & 98 & 99 & $\mathrm{D}$ \\
\hline 1.0 & 99 & $\mathrm{D}$ & & & \\
\hline 2.5 & 99 & 99 & 99 & $\mathrm{D}$ & \\
\hline 2.5 & 99 & $\mathrm{D}$ & & & \\
\hline 5.0 & D & & & & \\
\hline 5.0 & $\mathrm{D}$ & & & & \\
\hline $5.0(\mathrm{AC} 217,300)^{* *}$ & 99 & $\mathrm{D}$ & & & \\
\hline Check & 0 & 0 & 0 & 1 & 5 \\
\hline
\end{tabular}

$* \mathrm{D}=$ death of colony.

**AC 217,300 (Amdro) was used as the standard.

not statistically significant. Evaluations for 21 wks post-treatment showed no significant differences but it appeared that the low concentration of EL-468 was not as effective as the standard or the higher concentration of EL-468. EL-468 was applied at $2 \mathrm{X}$ and $4 \mathrm{X}$ the rate of $\mathrm{AC} 217,300$ in the standard (Amdro®) in these field tests, because a preliminary study indicated an equivalent (1X) rate per hectare gave a maximum of $60 \%$ control. However, more recent tests in Mississippi (Banks et al. unpublished data) have shown good control of RIFA with rates as low as $3.2 \mathrm{~g} / \mathrm{ha}$. Also, Williams et al. (1980) reported laboratory screening data for AC 217,300 that suggests that at the equivalent concentrations, the 2 compounds are equally toxic. It is possible that the apparent variations in results reflect formulation differences which will be resolved in subsequent studies under an Environmental Use Permit.

An obvious difference between EL-468 and AC 217,300 is that the former does not exhibit the specific effects on the colony queen that were noted with

TABLE 3. CONTROL OF RED IMPORTED FIRE ANTS WITH EL-468 IN FIELD TESTS in Hamilton County, FloRida. Each tReatment aPPlied to 3 1-ACRE PLOTS.

\begin{tabular}{|c|c|c|c|c|c|c|}
\hline \multirow[b]{2}{*}{ Chemical } & \multirow{2}{*}{$\begin{array}{l}\text { Conc. }(\%) \\
\text { in oil* }\end{array}$} & \multicolumn{2}{|c|}{ Application rate } & \multicolumn{3}{|c|}{$\begin{array}{c}\text { Percent control } \\
\text { after indicated wks** }\end{array}$} \\
\hline & & $\mathrm{kg} / \mathrm{ha}$ & $\mathrm{g} \mathrm{AI} / \mathrm{ha}$ & 6 & 12 & $\overline{21}$ \\
\hline EL-468 & 2.5 & 2.8 & 20 & $75 \mathrm{a}$ & $86 a$ & $72 a$ \\
\hline $\begin{array}{l}\text { EL-468 } \\
\text { AC_217.300 }\end{array}$ & 5.0 & 2.8 & 40 & $77 \mathrm{a}$ & $91 \mathrm{a}$ & $86 a$ \\
\hline $\begin{array}{l}\text { (Standard) } \\
\text { Untreated control }\end{array}$ & 2.5 & 1.4 & 10 & $\begin{array}{r}66 \mathrm{a} \\
7 \mathrm{~b}\end{array}$ & $\begin{array}{l}88 \mathrm{a} \\
11 b\end{array}$ & $\begin{array}{r}80 a \\
9 b\end{array}$ \\
\hline
\end{tabular}

* $30 \%$ Soybean oil on pregel defatted corn grits.

**Avg. 3 replications. Means in the same column not followed by the same letter are significantly different at the $5 \%$ level of confidence based on Duncan's multiple range test. 
the latter compound (Williams et al. 1980). Despite these facts, our data show that EL-468 is an effective delayed-action toxicant which could be an additional useful tool for the control of imported fire ants and possibly other pest ant species.

EL-468 can be referred to chemically as a phenylenediamine and thus it represents the second new class of chemicals that we have discovered that exhibit delayed toxicity.

\section{ACKNOWLEDGEMENTS}

The authors gratefully acknowledge the assistance of J. K. Plumley and D. M. Hicks in conducting the tests.

\section{LITERATURE CITED}

Alley, E. G. 1973. The use of mirex in control of the imported fire ant. J. Environ. Qual. 2: 52-61.

Baetcke, K. P., J. D. Cain, AND W. E. Poe. 1972. Residues in fish, wildlife, and estuaries: Mirex and DDT residues in wildlife and miscellaneous samples in Mississippi-1970. Pestic. Monit. J. 6: 14-22.

Banks, W. A., B. M. Glancey, C. E. Stringer, D. P. Jouvenaz, C. S. LOFGREN, AND D. E. WeIDHAAS. 1973. Imported fire ants: Eradication trials with mirex bait. J. Econ. Ent. 66: 785-9.

- C. S. LOFGREN, C. E. STRINGER, AND R. Levy. 1977. Laboratory and field evaluation of several organochlorine and organophosphorus compounds for control of imported fire ants. USDA, ARS, (Ser.) ARS-S$169,13 \mathrm{p}$.

- H. L. Collins, D. F. Williams, C. E. Stringer, C. S. Lofgren, D. P. HARLAN, AND C. L. MANGUM. 1981. AC-217,300, a new amidinohydrazone bait toxicant for control of the red imported fire ant. Southwest. Ent. 6: 158-64.

Harlan, D. P., W. A. Banks, H. C. Collins, and C. E. Stringer. 1981. Evaluation of an amidinohydrazone bait for control of imported fire ants in Alabama, Louisiana, and Texas. Southwest. Ent. 6: 150-57.

Innes, J. R., B. M. Ulland, M. G. Valerio, L. Petrucelli, L. Fishbein, E. R. Hart, A. J. Pallatta, R. R. Bates, H. L. Falls, J. J. Gart, M. Klein, I. Mitchell, AND J. Peters. 1969. Bioassay of pesticides and industrial chemicals for tumorigenicity in mice: a preliminary note. J. Natl. Cancer Inst. 42: 1101-4.

LOFGREN, C. S., F. J. BARTLETT, AND C. E. STRINGER. 1963. Imported fire ant toxic bait studies: Evaluation of carriers for oil baits. J. Econ. Ent. $56: 62-6$.

, AND W. A. BANKs. 1964. Imported fire ant toxic bait studies: Further tests with granulated mirex-soybean oil bait. J. Econ. Ent. 57: 695-8.

Lowe, J. I., P. R. Parrish, A. J. Wilson, JR., P. D. Wilson, and T. W. DULSE. 1971. Effects of mirex on selected estuarine organisms. Trans. North American Wildl. Nat. Res. Conf. 36: 171-86.

$\longrightarrow$, P. D. Wilson, AND R. B. Davison. 1970. Effects of mirex on crabs, shrimp, and fish. United States Dept. Inter. Cir. 335: 22-3.

LUdKe, J. L., M. T. FINLEY, AND L. LUSK. 1971. Toxicity of mirex to crayfish, Procambarus blandingi. Bull. Environ. Contam. Toxicol. 6: 89-96.

Mehendale, H. M., L. Fishbein, M. Fields, and H. B. Matthews. 1972. Fate of mirex- ${ }^{-14} \mathrm{C}$ in the rat and plants. Bull. Environ. Contam. Toxicol. 8: 200-7. 
MraK, E. M., Chairman. 1969. Report of the Secretary's Commission on Pesticides and Their Relationship to Environmental Health. Parts I and II. 677 p. United States Dept. Health, Ed. and Welfare.

Williams, D. F., C. S. Lofgren, W. A. Banks, C. E. Stringer, and J. K. Plumley. 1980. Laboratory studies with nine amidinohydrazones, a promising new class of bait toxicants for control of red imported fire ants. J. Econ. Ent. 73: 798-802. 